Egyptian Veterinary Medical Society of Parasitology Journal

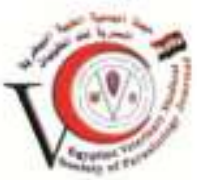

Original Article

\title{
Assessment of Cephalopina titillator, different prepared antigens in diagnosis by indirect ELISA in serum and mucus of camels
}

Eman A. A. Hassanen and Mona Mohammed I. Abdel Rahman

Parasitology Dept., Faculty of Vet. Med., Zagazig University. Zagazig, Egypt

*Corresponding author: mona_111_para@yahoo.co m

01124983310

\begin{abstract}
:
Cephalopina titillator infestation cause great economic losses where the infested camels show different clinical signs which varied from loss of appetite, decrease in body weights, and milk production to impaired breathing. In the current study, the prevalence of $C$. titillator was recorded by PM examination and indirect ELISA in serum and mucus samples as $26.27 \%, 83.33 \%$, and $51.67 \%$, respectively. Also, the study showed a highly significant relation between the sample sources (serum/mucus) and the antigen types (Excretory Secretory Products ESP, Organ 's content Co, Crude Cr \& Somatic So Ags) depending upon the obtained res ults by indirect ELISA. The usage of different antigens showed a significant variation in the obtained results by ELISA test, where Co Ag recorded the highest values followed by ESP and finally, So Ag showed the lowest values. The recorded results for indirect ELISA showed that the use of Co Ag for antibody detection in serum samples showed the highest significant values in comparison with other used Ags . Area under Curve (AUC) referred to a good diagnostic accuracy of ELISA test where it reached 0.73 for Co Ag and ESP. The obtained results illustrated moderate to high significant agreement between PM examination and ELISA test. The stu dy concluded that using an indirect ELISA against different third instar antigens of $C$. titillator reported higher values in serum than mucus. The strength of antigen immunogenicity was arranged as: $\mathrm{Co}>\mathrm{Cr}>\mathrm{ESP}>\mathrm{So}$ in serum, and it was ESP > $\mathrm{Cr}>\mathrm{Co} \&$ So in mucus. Also, the use of $\mathrm{Co} \mathrm{Ag}$ for the serum samples in ELISA considered the most immunogenic one which enhance IgG production and recommends its use for early and accurate serodiagnosis of $C$. titillator infestation in naturally infected camels.
\end{abstract}

Keywords: Antigen, Cephalopina titillator, Crude, immunogenicity, mucus

\section{INTRODUCTION}

Camel is considered a multipurpose animal which used for transport and production include meat, milk and hides Buchnev et al. 1987. Parasitic infestation is a major risk to camel production in desert and semi-desert areas. Cephalopina titillator is one of the most important and pathogenic parasites infest camels and caused condition called nasopharyngeal myiasis. Their adult flies were reported in sub-Saharan Africa, Middle East, Australia and Asia Taylor et al. 2007; Wall and Shearer 2001. Parasitic infestations 
with $C$. titillator might reduce milk and meat production, decrease efficiency of working, impaired fertility, lower calving rates, death in camels and consequently high economic losses.

The larvae were mainly detected during the postmortem examination of the nasal cavities, frontal sinus and pharynx of slaughtered camels Sazmand and Joachim 2017. Also, they were detected in the lungs $(10 \%)$ of the examined dromedaries in Iran (Oryan et al. 1993). The larvae induce irritation and severe mucosal damage, which is manifested by snorting, extensive sneezing, restlessness, head shaking, nostril bleeding, coughing, reduced milk production, decrease in body weights and off food, especially during the emergence of mature larvae from the nostrils Taylor et al. 2007. In heavy infestations, the previous nasopharyngeal lesions caused by larvae may be transformed into pyogenic infections and pneumonia due to secondary bacterial invasion Kettle 1995; Musa et al. 1989 and Zumpt 1965. These cases must be differentiated from central nervous disturbances Kaufmann 1996. In addition, the larvae might reach the thyroid gland of camels and induce functional disturbances Abd El-Rahman 2010.

The female flies attracted to lay their larvae upon the nostrils of camels. The larvae directed inside the nasal passages and paranasal sinuses to molt twice and remained attached to the nasopharynx and mucus membrane for up to 11 months. They depend upon the debris of mucosa for feeding and induce severe irritation and tissue damage, according to the intensity of infestation Oryan et al. 2008 and Shakerian et al. 2011.

The infection rate with $C$. titillator reached $90 \%$ in camel herds Wall and Shearer 2001. In Sudan, all the examined camels were suffered from heavy infestation which reached up to 250 larvae / head Kettle 1995; Musa et al. 1989 and Zumpt 1965. However, in Al Arish Abattoir, North Sinai Governorate, Egypt the rate reached 25\% by Morsy et al. 1998.

Immune response of the host against larvae causing myiasis depend upon the host general health, biology and predilection site of larvae, antigen types and the specific immune defense against the parasitized larvae. Larvae stimulate specific and nonspecific immune responses. Larvae induce innate and adaptive immune responses in the host where Ags stimulates natural killer (NK) cells, which produce interferon $\mathrm{Y}$ (IFN- $\mathrm{Y}$ ) to activate $\mathrm{T}$ helper cells (cellular immune response) which enhance $B$ cells to produce lgs (humoral immune response) Otranto 2001. Immunological tests were considered as alternative way to postmortem examination for diagnosis of larvae causing myiasis. They help in easy, low cost and effective diagnosis, especially in live animals. Also, their ability to detect infection in case of low or difficult detectable larvae in the animal body (released outside the host) by PM examination. So, the current study aimed to: 
I. Determine prevalence of $C$. titillator in camels by PM examination and indirect ELISA test.

II. Explore the usage of anti- $C$. titillator antibody detection in camels by ELISA in mucus and serum.

III. Characterize and evaluate different $C$. titillator larval antigens from 3rd instars.

IV. Distinguish the significance of the obtained results via PM examination and indirect ELISA.

$\mathrm{V}$. Detect the diagnostic accuracy of indirect ELISA.

\section{MATERIAL AND METHODS}

\section{Animals}

One hundred and twenty adult camels (80 male and 40 female, 2-3 years old) were examined before and after slaughtering at the main slaughterhouse of Belbies City, Sharkia Province, Egypt for Cephalopina titillator infestation. After slaughtering, their heads were dissected and examined for the larvae and induced PM lesions in the nasal cavities, frontal sinuses, turbinate bones and nasopharyngeal areas.

\section{Sampling}

Blood samples and mucus swabs were collected from the examined camels in clean test tubes. The clotted blood samples were centrifuged at $3000 \mathrm{rpm} / 10$ minutes for obtaining serum. The mucus swabs were gently mixed with phosphate buffered' saline (for 2 hours and then centrifuged at 3000 $\mathrm{rpm} / 10$ minutes. The samples were kept frozen at $-20^{\circ} \mathrm{C}$ until further examination.

\section{Larvae collection}

The larvae were collected from the examined camels after slaughtering.
The third instars (L3) were washed several times with PBS.

\section{Antigens preparation}

They were prepared from L3 as the described by Hendawy et al. 2013 and Tabouret et al. 2001

- Excretory Secretory Products (ESP) Ag:

L3 were incubated in PBS (1larva/1ml, pH 7.2) containing streptomycin over night at room temperature in a dark bottle. The collected solution was filtrated, centrifuged and kept at $-20^{\circ} \mathrm{C}$.

- Organ's content (Co) Ag:

The whole digestive tract and the salivary glands were collected from the dissected L3 and then centrifuged to obtain supernatant which stored at $-20^{\circ} \mathrm{C}$.

- Crude (Cr) Ag:

The whole larvae were homogenized in PBS, sonicated, exposed to freeze-thawing 3 times, centrifuged at $12000 \mathrm{rpm}$ for $30 \mathrm{~min}$. in cooling centrifuge and then, the supernatant was kept at $-20^{\circ} \mathrm{C}$.

- Somatic (So) Ag:

The outer layering cuticle was separated, washed several times with PBS, and then continued as crude Ag.

\section{Protein concentration measurement}

Total proteins concentrations in the four different antigens $(\mathrm{Cr}$, Co, So and ESP) were measured by Bradford method. The optical densities were measured at $450 \mathrm{~nm}$.

\section{Enzyme Linked Immunosorbent Assay (ELISA) procedures}

ELISA plates were coated overnight at $4^{\circ} \mathrm{C}$ with $5 \mu \mathrm{g} / \mathrm{ml}$ of $C$. titillator antigens. The plates were 
washed three times with $0.05 \%$ PBSTween 20 and blocked by 10\% skimmed milk in PBS for 2 hours at $37^{\circ} \mathrm{C}$. After three repeated washings, $100 \mu \mathrm{l} /$ well of duplicate dilution of sera (sera diluted 1:100 in PBS-T) was added per well and incubated for one hour at $37^{\circ} \mathrm{C}$. The sera were removed by three repeated washings and $100 \mu \mathrm{l} /$ well of $1: 1000$ protein Aperoxidase (HPR) from Staphylococcus aureus horse radish incubated for one hour at $37^{\circ} \mathrm{C}$. After three washings of plates with PBS-T, $100 \mu \mathrm{l} /$ well of the O-phenylene diamine in substrate buffer were added and re-incubated in darkness for $15-30 \mathrm{~min}$ at $37^{\circ} \mathrm{C}$. Stopping the reaction by adding a $100 \mu \mathrm{l} /$ well $1 \mathrm{~N}$ sulphuric acid and read the optical densities (OD) by ELISA reader multiscan thermos scientific at wavelength $450 \mathrm{~nm}$. Results were expressed as OD and the positive threshold was determined to be twofold the mean cutoff value of negative sera.

\section{Statistical analyses}

Recorded data were analyzed using the statistical package for social sciences (SPSS), version 25 (Armonk, NY: IBM Corp), Graph Pad prism 8.0.2 (Graph Pad Software, Inc) and Med Calc version 15.6 - (C) 19932015 Med Calc Software bvba. Quantitative data were expressed as mean \pm standard error (SE). Qualitative data were expressed as frequency and percentage. The following tests were done:

- Two-way ANOVA was run to test differences among different antigens in serum and mucus samples. Tukey's honesty significant difference test was run as a posthock test.

- Receiver operating characteristic (ROC curve) analysis was used to find out the overall the predictivity of parameter, and to find out sensitivity and specificity at this cutoff value (Savini et al. 1997).

Sensitivity $=($ true $+v e) /[($ true $+v e)+$ (false -ve)].

Specificity $=($ true $-v e) /[($ true $-v e)+$ (false +ve)].

$\mathrm{PPV}=($ true $+\mathrm{ve}) /[($ true $+\mathrm{ve})+($ false $+\mathrm{ve})]$.

$\mathrm{NPV}=($ true $-\mathrm{ve}) /[($ true $-\mathrm{ve})+($ false $-v e)]$.

Accuracy $=(\mathrm{TP}+\mathrm{TN}) /[\mathrm{TP}+\mathrm{FP}+\mathrm{TN}+\mathrm{FN}]$

- Z-test used for comparing AUC (which indicate diagnostic accuracy) of two diagnostic tests. The optimal cut-off points between positive and negative samples were estimated using the Youden index (Yin and Tian 2014), maximizing the difference between sensitivity and specificity. The degree of agreement between the methods after categorization according to optimal cut-off was measured using the Cohen's kappa coefficient where $\mathrm{k}=1.00-0.81$ nearly perfect; $\mathrm{k}=0.80$ 0.61 good; $\mathrm{k}=0.60-0.41$ moderate; $\mathrm{k}=0.40-0.21$ weak; $\mathrm{k}=0.20-0$ poor; and $\mathrm{k}<0$ absence of agreement. The confidence interval was set to $95 \%$ and the margin of error accepted was set to $5 \%$. So, the $p$ value was considered significant as the following:

Probability (P-value)

P-value $<0.05$ was considered significant.

P-value $<0.001$ was considered as highly significant.

P-value $>0.05$ was considered insignificant.

GraphPad Prism 8.0 was used for presenting data like scatter plots. 


\section{RESULTS}

\section{Clinical examination of tested camels}

The noticed clinical signs included appetite loss, congested mucus membrane, increase in body temperature, enlargement of lymph nodes, nasal discharge, neurological signs, increase respiratory rate, sneezing and snoring during breathing.

\section{PM examination}

C. titillator larvae were mainly detected in the nasal cavities, frontal sinuses and turbinate bones of infested camels. The cavities appeared congested, inflamed and blocked by thick bloody stained mucus due to the presence of strongly attached larvae. The prevalence of infection reached $26.27 \%$.

\section{Indirect ELISA test}

IgG values against $C$. titillator in the mucus and serum of infested and apparently healthy camels were determined using Indirect ELISA, coated with antigens from contents (Co), whole larvae crude Ag extract (Cr), outer cuticle (So) and excretory-secretory products (ESP) of 3rd larval instars. The different prepared Ags were evaluated via calculation of their sensitivity, specificity, positive predictive value (PPV), negative predictive value (NPV), apparent prevalence and accuracy in the examined serum and mucus samples.

By indirect ELISA, the prevalence values reached $51.67 \%$ in Co, $13.33 \%$ in So, $20 \%$ in ESP and $\mathrm{Cr}$ Ags in mucus samples. Also, they were $65 \%$ in ESP, $70 \% \mathrm{Cr}$, $76.67 \%$ Co, $83.33 \%$ So in serum samples of camels

There was a highly significant relation between the sample sources (serum/mucus) and the antigen types (ESP, Co, $\mathrm{Cr}$ \& So) depending upon the obtained results by indirect ELISA test where $\mathrm{P}<$ 0.01 . In the current study, the recorded results for ELISA showed that the use of $\mathrm{Co} \mathrm{Ag}$ for antibody detection in serum samples showed the highest significant values (1.66 $\pm 0.04^{\mathrm{a}}$ ) in comparison with other used Ags for serum and mucus samples. $\mathrm{Cr}$ Ag used for detection of Abs in serum showed a significant reduction in the obtained readings $\left(1.18 \pm 0.059^{b}\right)$ and did not show any significant differences between serum and mucus $\left(0.99 \pm 0.045^{\mathrm{bc}}\right)$. ELISA readings obtained by ESP Ag showed significant reduction in comparison with those obtained by $\mathrm{Co} \mathrm{Ag}$ and $\mathrm{Cr}$ Ag. Also, ESP Ag showed non-significant difference between serum $(0.98 \pm 0.039 \mathrm{c})$ and mucus $\left(0.97 \pm 0.05^{c}\right)$ samples. So $\mathrm{Ag}$ recorded the lowest reading in serum samples $(0.43 \pm 0.034 \mathrm{e})$. In mucus samples, the obtained readings for $\mathrm{Co} \mathrm{Ag}$ and So $\mathrm{Ag}$ did not show significant difference $(0.65$ $\pm 0.024^{d}$ ). The main effect of source of sample showed a significant results $P<0.05$, where the use of serum samples appeared significantly higher $(1.07 \pm 0.04 \mathrm{a})$ than the mucus $\left(0.83 \pm 0.02^{b}\right)$. The usage of different antigens showed 
a significant variation in the obtained results by ELISA test, $p<0.05$, where Co $\mathrm{Ag}$ recorded the highest values $\left(1.18 \pm 0.05^{\mathrm{a}}\right)$ followed by ESP Ag $\left(0.97 \pm 0.03^{b}\right)$ and So $\mathrm{Ag}$ showed the lowest values $\left(0.54 \pm 0.02^{c}\right)$. However, $\mathrm{Cr} \mathrm{Ag}$ didn't show significant difference in comparison with $\mathrm{Co} \quad \mathrm{Ag}$ (1.09 $\left.\pm 0.04^{\mathrm{ab}}\right)$. Fig. 1 and Table 1

\section{Accuracy of indirect ELISA by different $C$. titillator Ags}

In serum samples, Area under Curve (AUC) reached 0.73 in $\mathrm{Co} \mathrm{Ag}$ which was referred to a good diagnostic accuracy of ELISA test. It reached 0.69 in $\mathrm{Cr} \mathrm{Ag}$ that indicated a sufficient diagnostic accuracy, while of ESP and So Ags reached 0.55 and 0.57 , respectively, which indicate bad diagnostic accuracy. The difference in AUC between Co $\mathrm{Ag}$ and So was 0.16 which considered statistically significant $(P$ $<0.05)$. In addition, the difference between ESP (0.55) and Co (0.73) resulted in higher difference $(0.182)$ more than those obtained using other antigens. Table 2 and Fig. 2

In mucus sample, AUC was (0.73) in ESP Ag that considered good diagnostic accuracy of the ELISA. In case of $\mathrm{Cr} \mathrm{Ag}, \mathrm{AUC}$ was 0.64 that indicated a sufficient diagnostic accuracy, while in cases of $\mathrm{Co} \mathrm{Ag}$ and So $\mathrm{Ag}$, they were 0.57 and 0.55 respectively which indicate bad diagnostic accuracy. The difference in AUC between ESP (0.73) and So Ag (0.57) reached 0.176 which considered statistically significant $(P<0.05)$. Table 3 and Fig. 3

\section{Different evaluation parameters of different Ags by ELISA}

In serum samples, Co, $\mathrm{Cr}$ and So Ags sensitivity was (100\%) which was higher than that ESP (84.21\%). Specificity of ESP and $\mathrm{Cr}$ Ags in serum was $43.9 \%$, while of $\mathrm{Co}$ and So Ags reached $34.15 \%$ and 26.83\%, respectively. Positive predictive value (PPV) was 45.24\% in $\mathrm{Cr} \mathrm{Ag}$, followed by $41.3 \%$ for ESP and Co Ags and $35.85 \%$ for so Ag. Negative predicted value (NPV) of Co, Cr, So Ag reached $100 \%$, which was higher than that of ESP (85.71\%).

In mucus samples, $\mathrm{Co} \mathrm{Ag}$ sensitivity was (75\%) which was higher than that ESP and $\mathrm{Cr}$ Ags $(50 \%)$, while it reached $25 \%$ in case of So Ag. Specificity of ESP and Cr Ags was $100 \%$, followed by $90.91 \%$ for So Ag. The lowest percentage was reached $56.82 \%$ for Co Ag. The PPV was $66.67 \%$ in ESP and $\mathrm{Cr}$ Ags, which followed by $50 \%$ in So $\mathrm{Ag}$ and finally, $38.71 \%$ in Co Ag. NPV was $86.21 \%$ in Co $\mathrm{Ag}$ followed by $83.33 \%$ in ESP and $\mathrm{Cr}$ Ags and then $76.92 \%$ in So Ag. Table 3.

The power of association or the degree of agreement between the ELISA and PM was evaluated using Kappa (k) statistics and the results illustrated that there were moderate (Co Ag) to high (ESP and Cr Ags) significant agreement between PM examination and ELISA test for mucus samples $(k=0.444, p<0.01)$ Also, it illustrated moderate significant agreement (ESP, Co and $\mathrm{Cr}$ Ags, $\mathrm{k}=0.22,0.25$ and.033, respectively). However, So $\mathrm{Ag}$ had week and non-significant agreement 
in both serum and mucus samples $(k=0.17-0.18)$. Table 4

Table 1: ELISA antibody values in camel serum and mucus using different Ags from 3rd instar of $C$. titillator.

\begin{tabular}{|c|c|c|}
\hline \multicolumn{3}{|c|}{ Interaction effect } \\
\hline & Serum & Mucus \\
\hline ESP Ag & $0.98 \pm 0.039 c$ & $0.97 \pm 0.05^{c}$ \\
\hline Co Ag & $1.66 \pm 0.04^{a}$ & $0.69 \pm 0.045^{d}$ \\
\hline $\mathrm{Cr} \mathrm{Ag}$ & $1.18 \pm 0.059^{b}$ & $0.99 \pm 0.045^{b c}$ \\
\hline So $\mathrm{Ag}$ & $0.43 \pm 0.034^{e}$ & $0.65 \pm 0.024^{d}$ \\
\hline \multicolumn{3}{|c|}{ Main effect of source of sample } \\
\hline Serum & \multirow{2}{*}{\multicolumn{2}{|c|}{$\begin{array}{l}1.07 \pm 0.04^{a} \\
0.83 \pm 0.02^{b}\end{array}$}} \\
\hline Mucus & & \\
\hline \multicolumn{3}{|c|}{ Main effect of Antigen } \\
\hline ESP Ag & \multirow{4}{*}{\multicolumn{2}{|c|}{$\begin{array}{l}0.97 \pm 0.03^{\mathrm{b}} \\
1.18 \pm 0.05^{\mathrm{a}} \\
1.09 \pm 0.04^{\mathrm{ab}} \\
0.54 \pm 0.02^{\mathrm{c}}\end{array}$}} \\
\hline $\mathrm{Co} \mathrm{Ag}$ & & \\
\hline $\mathrm{Cr} \mathrm{Ag}$ & & \\
\hline So $\mathrm{Ag}$ & & \\
\hline
\end{tabular}

Data are presented as mean \pm SE. Means followed by different small letters within each column are significantly different (Two-way ANOVA, Tukey test, $\mathrm{P} \leq 0.05$ ) 
Table 2: Pairwise comparison of ROC curves between different Ags

\begin{tabular}{|l|l|l|l|l|l|}
\hline & Variable & $\begin{array}{l}\text { Difference between } \\
\text { areas (AUROC) }\end{array}$ & SE a & z statistic & P value \\
\hline \multirow{4}{*}{ Mucus } & ESP vs Co & 0.153 & 0.116 & 1.327 & 0.1846 \\
\cline { 2 - 6 } & Co vs Cr & 0.0625 & 0.13 & 0.479 & 0.63 \\
\cline { 2 - 6 } & Cr vs So & 0.085 & 0.107 & 0.795 & 0.426 \\
\cline { 2 - 6 } & So vs ESP & $0.176^{*}$ & 0.08 & 1.998 & 0.0458 \\
\cline { 2 - 6 } & ESP v Cr & 0.091 & 0.074 & 1.24 & 0.216 \\
\cline { 2 - 6 } & Co vs So & 0.023 & 0.092 & 0.25 & 0.805 \\
\hline \multirow{6}{*}{ Serum } & ESP vs Co & $0.182^{*}$ & 0.0596 & 3.06 & 0.002 \\
\cline { 2 - 6 } & Co vs Cr & 0.041 & 0.0755 & 0.544 & 0.587 \\
\cline { 2 - 6 } & Cr vs So & 0.114 & 0.082 & 1.40 & 0.16 \\
\cline { 2 - 6 } & So vs ESP & 0.027 & 0.101 & 0.268 & 0.788 \\
\cline { 2 - 6 } & ESP vs Cr & 0.141 & 0.094 & 1.509 & 0.13 \\
\cline { 2 - 6 } & Co vs So & $0.155^{*}$ & 0.066 & 2.34 & 0.02 \\
\hline
\end{tabular}

* Significant

Table 3: Immunodiagnostic predictive values of ELISA (based on PM as standard gold) of serum and mucus samples in different antigens based on ROC curve reading.

\begin{tabular}{|l|l|l|l|l|l|l|l|l|}
\hline & \multicolumn{9}{l|}{ Serum } & \multicolumn{3}{l|}{ Mucus } \\
& ESP & Co & Cr & So & ESP & Co & Cr & So \\
\hline Cut-off & $>0.91$ & $>1.53$ & $\leq 1.5153$ & $>0.1088$ & $>1.41$ & $>0.66$ & $>1.39$ & $>0.87$ \\
\hline $\begin{array}{l}\text { AUC } \\
\text { C.I) }\end{array}$ & 0.55 & 0.73 & 0.69 & 0.57 & 0.73 & 0.57 & 0.64 & 0.55 \\
\hline Sensitivity & $84.21 \%$ & $100 \%$ & $100 \%$ & $100 \%$ & $50 \%$ & $75 \%$ & $50 \%$ & $25 \%$ \\
\hline Specificity & $43.9 \%$ & $\begin{array}{l}34.15 \\
\%\end{array}$ & $43.9 \%$ & $26.83 \%$ & $100 \%$ & $56.82 \%$ & $100 \%$ & $90.91 \%$ \\
\hline PPV & $41.3 \%$ & $41.3 \%$ & $45.24 \%$ & $35.85 \%$ & $66.67 \%$ & $38.71 \%$ & 66.67 & $50 \%$ \\
\hline NPV & $85.71 \%$ & $100 \%$ & $100 \%$ & $100 \%$ & $83.33 \%$ & $86.21 \%$ & $83.33 \%$ & $76.92 \%$ \\
\hline Accuracy & $56.67 \%$ & $55 \%$ & $61.67 \%$ & $48.33 \%$ & $80 \%$ & $61.67 \%$ & $80 \%$ & $73.33 \%$ \\
\hline Prevalence & $65 \%$ & $76.67 \%$ & $70 \%$ & $83.33 \%$ & $20 \%$ & $51.67 \%$ & $20 \%$ & $13.33 \%$ \\
\hline
\end{tabular}

AUC: a rea under curve, Co: organ content, Cr: crude, ESP: execratory secretory products, NPV:

negative predictive value, PPV: positive predictive value, So: somatic 
Table 4: Testing agreement between ELISA and PM examination in discriminating results in serum and mucus samples for different four antigens

\begin{tabular}{|l|l|l|}
\hline Sample & $\begin{array}{l}\text { Diagnostic tests } \\
\text { EllSA and PM }\end{array}$ & $\begin{array}{l}\text { Kappa value } \\
(\mathrm{k})\end{array}$ \\
\hline \multirow{4}{*}{ Mucus } & ESP & $0.444^{* \star *}$ \\
\cline { 2 - 3 } & Co & $0.25^{\star \star}$ \\
\cline { 2 - 3 } & Cr & $0.444^{* \star}$ \\
\cline { 2 - 3 } & So & $0.189 \mathrm{NS}$ \\
\hline \multirow{5}{*}{ Serum } & ESP & $0.22^{* \star}$ \\
\cline { 2 - 3 } & Co & $0.25^{\star *}$ \\
\cline { 2 - 3 } & Cr & $0.331^{* \star}$ \\
\cline { 2 - 3 } & So & $0.17 \mathrm{NS}$ \\
\cline { 2 - 3 } & ESP & $0.444^{\star * *}$ \\
\hline
\end{tabular}

*** Highly significant, **Moderate significant, NS: week and non-significant

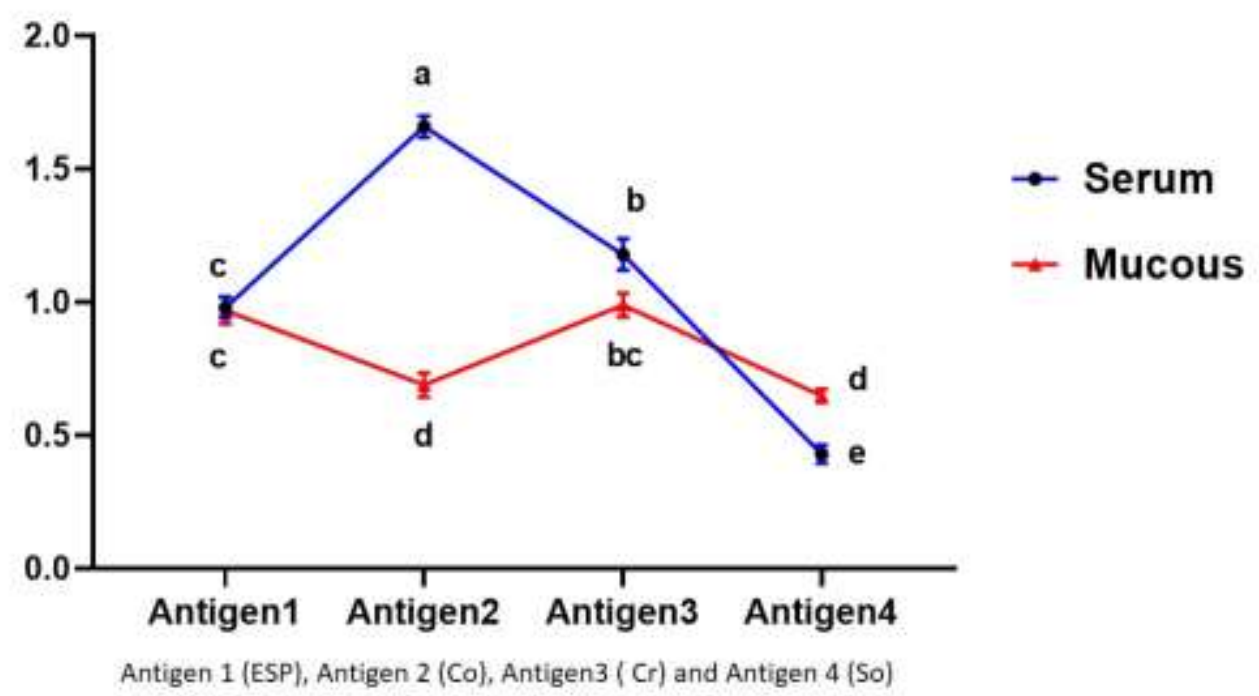

Fig 1: Significant relation between different Ags in serum and mucus samples 

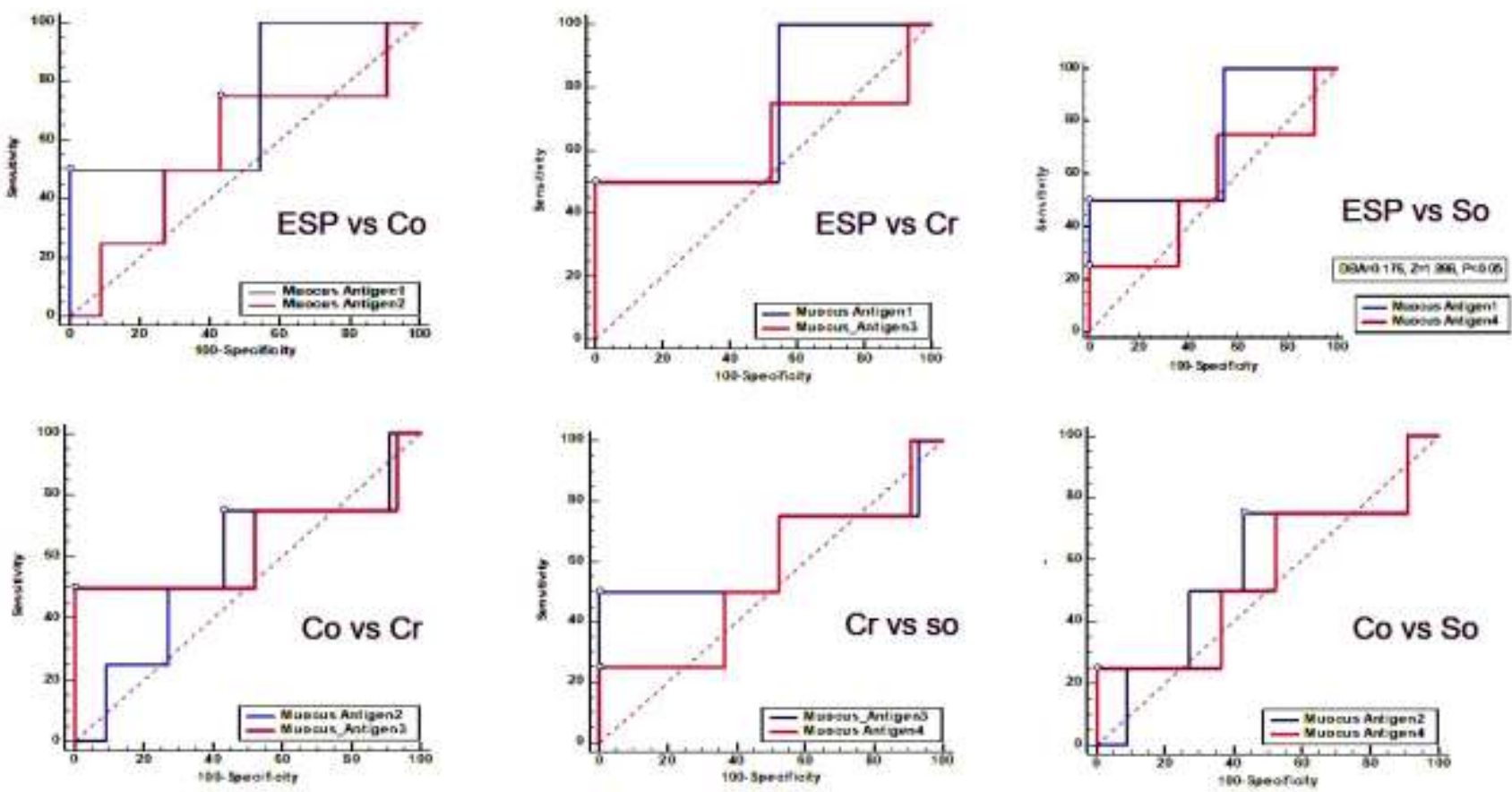

Fig. 2: Pairwise comparison of different Ags in serum samples by $Z$ test
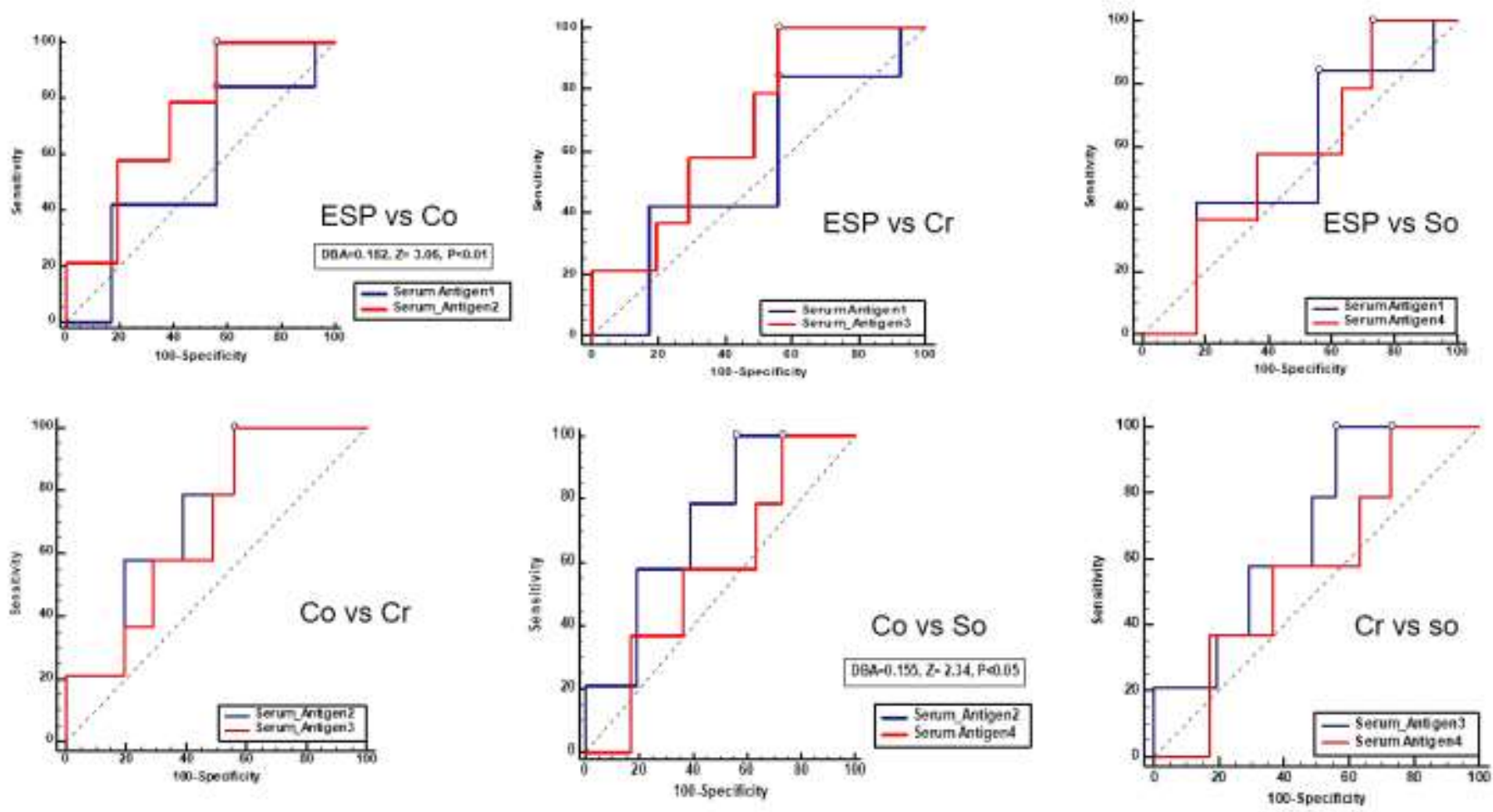

Fig. 3: Pairwise comparison of different Ags in mucus samples by $Z$ test 


\section{Discussion}

Nasopharyngeal myiasis caused by Cephalopina titillator (camel nasal bot) which very common in old world camelids is usually detected at necropsy or during PM inspection.

The observed clinical signs varied from loss of appetite to impaired breathing, which also noticed by Aljindeel et al. 2018; Bekele 2001 and Kissi and Assen 2017. The increase in body temperature resulted from the release of endogenous pyrogens during larval infestation which induced stimulation of the thermoregulatory center (Zumpt 1965). The observed signs were difficult to be differentiated from other caused by nervous or respiratory diseases. Also, the unavailability of commercial kits for detection of Abs against $C$. titllator made the current study aim to evaluate indirect ELISA test against PM examination (the gold standard test) for detection of $C$. titllator Abs in serum and mucus samples. Also, the study aimed to determine the accuracy of ELISA in screening Abs through the calculation of sensitivity, specificity, and prevalence.

The noticed PM lesions were differed according to the number of migrating larvae and their attachments inside the nasal cavities. The examination revealed copious mucus secretion stained with blood, petechial hemorrhage, congested mucus membranes and nasal passages. The latter was like the description of (Oryan et al. 2008) in Iran, (Abd El-Rahman 2010) in Libya and (Kissi and Assen 2017) in Ethiopia.
PM examination of slaughtered camels revealed that the prevalence of C. titllator was $26.27 \%$. Nearly similar rates were obtained by (Morsy et al. 1998) in Egypt to be 25\%, and by (AlRawashdeh et al. 2000) to be $33 \%$ in Jordan. Higher rates were recorded as the following: $82.6 \%$ in Ethiopica (Kissi and Assen 2017), 79\% in Libya (Abd El-Rahman 2010), $71.4 \%$ in Iran (Shakerian et al. 2011), 67.6\% in the eastern area Saudi Arabia (Amin 2005), $58.1 \%$ in Iran (Oryan et al. 2008), $52.3 \%$ in Iran (Jalali et al. 2016), 46.93\% in Jordan (Al-Ani and Amr 2016), $41 \%$ in Saudi Arabia (Alahmed 2002), 40.07\% in Iraq (Aljindeel et al. 2018). However, the highest rate was reported by (Musa et al. 1989) in western Sudan to be $100 \%$

By indirect ELISA the prevalence rate reached $83.33 \%$. Nearly similar percentage was recorded to be $90 \%$ by (Attia et al. 2020) in Egypt and lower percentage was $65.95 \%$ by (Toaleb and Abdel-Rahman 2021) in Egypt. The obtained percentages in the current study were $83.33 \%, 76.67 \%, 70 \%$ and $65 \%$ in So, Co, $\mathrm{Cr}$ and ESP Ags, respectively, which appeared nearly similar to that obtained by (Hendawy et al. 2013) in Egypt.

This difference in prevalence might be attributed to seasonal variation [in warm season larvae released outside host and was ready to pupate, increase seeking activity of adult flies in warm days (Cepeda-Palacios et al. 1998)], sex (sex hormones), breeding system (lactation period in females), continuous exposure to larvae, immunosuppression caused by increasing age of the host or 
by parasite itself [recurrent infestation induced decrease in lymphocytic proliferation (Jacquiet et al. 2005)]

Immunological tests were considered as alternative way to postmortem examination for diagnosis of larvae causing myiasis. They help in easy, low cost and effective diagnosis, especially in live animals. Also, their ability to detect infection in case of low or difficult detectable larvae in the animal body (released outside the host) by PM examination. ELISA test had made it possible to perform a serological test on sera and mucus samples for early diagnosis of $C$. titillator infestation. IgG values against C. titillator in mucus and serum samples from infested and apparently healthy camels were determined using indirect ELISA, coated with antigens from contents (Co), whole larvae crude Ag extract $(\mathrm{Cr})$, the outer cuticle (So) and excretory secretory products (ESP) of 3rd larval instars.

In serum sample, $\mathrm{Co}, \mathrm{Cr}$ and So Ags showed higher sensitivity and NPV $(100 \%)$ than those calculated for ESP $(84.21 \%$ and $85.71 \%$, respectively). However, ESP showed the highest specificity (43.9\%). This might be attributed to increase in nutrient intake and feeding activity of third instar accompanied with increase the size of secretory organs and so the increase immune response to produce higher quantities of specific IgG against ESP Ag which explained by Hendawy et al. 2013; Tabouret et al. 2003 and Yousef et al. 2016. $\mathrm{Cr} \mathrm{Ag}$ obtained the highest PPV (45.24\%) followed by ESP and Co Ags (41.3\%) and then So Ag $(35.85 \%)$. This might be due to the cumulative effect of the proteins produced from the cuticle and internal organs forming $\mathrm{Cr} \mathrm{Ag}$, where (Innocenti et al. 1997) reported that proteins raised from cuticle were able to activate the host immune system during or immediately after molting of larval stages. On the other hand, (Toaleb and Abdel-Rahman 2021) recorded higher evaluation parameters for $\mathrm{Cr} \mathrm{Ag}$ included $100 \%$ sensitivity, $96.88 \%$ specificity, $94.12 \%$ PPV, and 100\% NPV in Egypt.

The currently obtained results from ELISA in serum by $\mathrm{Co} A \mathrm{Ag}$ and those recorded by (Attia et al. 2020) shared the same sensitivity percentage (100\%) but the previously calculated specificity and accuracy percentages by Attia et al. 2020 were higher $(50 \%$ and $90 \%$, respectively) than those calculated in the current study $(34.15 \%$ and $55 \%$, respectively). This might be due to using the whole internal content in this study instead of salivary gland only in the previous study and higher used cut off value in this study (1.53 instead of 0.40). The degree of agreement between the ELISA and PM by Kappa (k) was compatible with the obtained by Attia et al. 2020.

In mucus samples, ESP and $\mathrm{Cr}$ Ags showed the highest immunogenicity where specificity and PPV reached $100 \%$ and $66.67 \%$, respectively, followed by Co $\mathrm{Ag}$ which showed moderate immunogenicity where sensitivity and NPV were $75 \%$ and $86.21 \%$, respectively. Finally, So $\mathrm{Ag}$ obtained the lowest percentages. The current immunogenic values for ESP extracted from third instar were similar to the values of Yousef et al. 2016 study. 
Variation between values obtained from mucus and serum samples might be attributed to differences in production and distribution of local and systemic IgG against larval infestation.

In mucus samples, ESP $\mathrm{Ag}$ prepared from $L 3$ had a good diagnostic accuracy of ELISA test which was compatible with the results of Frugere et al. 2000 and Yousef et al. 2016 and despite obtaining non-significant difference between using ESP in serum $(0.98 \pm 0.039 c)$ and mucus samples.

In serum samples, Co $\mathrm{Ag}$ prepared from L3 showed the highest significant values $(1.66 \pm 0.04$ a) in comparison with other used Ags where Co Ag intensely stimulated the production of Abs inside the infected hosts Angulo-Valadez et al. 2009 and Tabouret et al. 2003. Accordingly, Co Ag considered the best immune-stimulant to induce a profuse production of $\operatorname{lgG}$ against $C$. titillator. This was compatible with reports of Attia et al. 2020 and Hendawy et al. 2013.

The currently studied different prepared antigens were developed variable results according to the protein structure of Ags, different immune responses (cellular/humoral), type of immunological test and modifications Hendawy et al. 2013. C. titillator able to stimulate cellular and humoral immunity due to the prolonged infestation period and their interaction with the immune system of infested camels Oryan et al. 2008 and Stevens et al. 2006.

\section{Conclusion}

This study evaluated using indirect ELISA test against different L3 antigens of $C$. titillator where the serum obtained higher values than mucus samples of the examined camels. In relation to different Ags, the strength of immunogenicity was arranged as: Co > $\mathrm{Cr}>\mathrm{ESP}>\mathrm{So}$ in serum, and it was ESP $>\mathrm{Cr}>\mathrm{Co} \& \mathrm{So}$ in mucus. The obtained results evaluated the use of $\mathrm{Co} \mathrm{Ag}$ for the serum samples in ELISA as the most immunogenic one which enhance IgG production and recommends its use for early and accurate serodiagnosis of $C$. titillator infestation in naturally infected camels. Plus, using indirect ELISA test for serodiagnosis will help in early planning of treatment (less economic loss) and preparation of monitoring and eradication programs.

\section{Acknowledgements}

Sincere thanks to Dr. Aliaa Abd ElRahman Abdallah Balegh (Researcher of Parasitology at Animal Health Research institute) for her technical assistance.

\section{References}

Abd El-Rahman, S. (2010): Prevalence and pathology of nasal myiasis in camels slaughtered in El-Zawia Province Western Libya: with a reference to thyroid alteration and renal lipidosis. Global Vet. 4:190-197.

Al-Ani, F.; and Amr, Z. (2016): Seasonal prevalence of the larvae of the nasal fly (Cephalopina titillator) in camels in Jordan. Revue. d'élevage et de médecine vétérinaire des pays tropic., 69: 125-127.

Al-jindeel, A.J.F.; Jasim, H.J.; Alsalih, J.N. and AI-Yasari, A.M.R. (2018): 
Clinical, immunological, and epidemiological studies of nasopharyngeal myiasis in camels slaughtered in Al-Muthanna Province. Mirror of Res. in Vet. Sci.and Anim., 7: 51-61.

Al-Rawashdeh, O.F.; Al-Ani, F.K.; Sharrif, L.A.; Al-Qudah, K.M.; Al-Hami, Y. and Frank, N. (2000): A survey of camel (Camelus dromedarius) diseases in Jordan. J. of Zoo and Wildlife Med., 31: 335-338.

Alahmed, A.M. (2002): Seasonal prevalence of Cephalopina titillator larvae in camels in Riyadh Region, Saudi Arabia. Arab Gulf J. Sci. Res., 20, 161-164.

Amin, A. (2005): Seasonal prevalence of Cephalopina titillator myiasis in camels Arab Gulf J. Scient. Res., 346367.

Angulo-Valadez, C.E.; CepedaPalacios, R.; Ascencio, F.; Jacquiet, P.; Dorchies, P.; Ramirez-Orduna, J.M. and Lopez, M.A. (2009): IgG antibody response against salivary gland antigens from Oestrus ovis L. larvae (Diptera: Oestridae) in experimentally and naturally infected goats. Vet.Parasitol.,161: 356-359.

Attia, M.M.; Farag, H.S.; Abdel-Saeed, H. and Ismael, E. (2020): Advanced immunological studies on Cephalopina titillator with special references to the epidemiological uses of Dot-ELISA in camel sera. J. of Parasitic diseases: official organ of the Indian Soc. for Parasito., 44: 813-821.

Bekele, T. (2001): Studies on Cephalopina titillator, the cause of 'Sengale' in camels (Camelus dromedarius) in semi-arid areas of Somali State, Ethiopia. Trop. Anim. Health Prod., 33: 489-500.
Buchnev, K.N.; Tulepbaev, S.Z. and Sansyzbaev, A.R. (1987): Infectious diseases of camels in the USSR. Rev. Sci. Tech. Off Int. Epiz., 6, 487-495.

Cepeda-Palacios, R.; Jiménez, M.L. and Armenta, J.A. (1998): Viabilidad del gusano del cuerno Oestrus ovis I. (Diptera: Oestridae)" durante los períodos de prepupa y pupa. In: Memorias del XXXIII Congreso Nacional de Entomología, Acapulco,Guerrero, México.

Frugere, S.; Cota, L.A.; Prevot, F.; Cepeda, P. R.; Tabouret, G.; Bergeaud, J.P.; Duranton, C.; Dorchies, P. and Jacquiet, P. (2000): Immunisation of lambs with excretory secretory products of Oestrus ovis third instar larvae and subsequent experimental challenge. Vet. Res., 31: 527-535.

Hendawy, S.H.M.; Allam, N.A.T.; Kandil, O.M.; Zayed, A.A.; Desouky, A.A.Y. and El-Seify, M.A. (2013): Immunological evaluation of the diagnostic values of Cephalopina titillator different larval antigens in camels from Egypt. Glo. Vet.,10: 158-164.

Innocenti, L.; Lucchesi, P. and Giorgi, F. (1997): Integument ultrastructure of Oestrus ovis (L.) (Diptera: Oestridae) larvae: host immune response to various cuticular components. Int. J. Parasitol., 27: 495-506.

Jacquiet, P.; Ngoc, T.T.T.; Nouvel, X.; Prévot, F.; Grisez, C.; Yacob, H.; Bergeaud, J.; Hoste, H.; Dorchies, P. and Tabouret, G. (2005): Regulation of Oestrus ovis (Diptera: Oestridae) populations in previously exposed and naïve sheep. Vet. Immun. and Immunopatho.,105: 95-103.

Jalali, M.H.R.; Dehghan, S.; Haji, A. and Ebrahimi, M. (2016): Myiasis caused by Cephalopina titillator (Diptera: 
Oestridae) in camels (Camelus dromedarius) of semi-arid areas in Iran: distribution and associated risk factors. Comparat. Clinical Pathol., 25: 677-680.

Kaufmann, J. (1996): Parasitic infections of domestic animals a diagnostic manual. Germany: Birkhäuser Verlag.

Kettle, D.S. (1995): Medical and veterinary entomology. U.K.: C.A.B. international, Wallingford. Oxon Ox 108 DE.

Kissi, L.M. and Assen, A.M. (2017): Prevalence, larvae burden and gross pathological lesion of Cephalopina titillator in camels slaughtered at Addis Ababa abattoir Akaki branch, Ethiopia. J. of Vet. Sci. \& Tech., 08: 1-5.

Morsy, T.A.; Aziz, A.S.; Mazyad, S.A. and Al Sharif, K.O. (1998): Myiasis caused by Cephalopina titillator (Clark) in slaughtered camels in $\mathrm{Al}$ Arish Abattoir, North Sinai governorate, Egypt. J. Egypt. Soc. Parasitol., 28: 67-73.

Musa, M.F.; Harrison, M.; Ibrahim, A.M. and Taha, T.O. (1989): Observations on sudanese camel nasal myiasis caused by larvae of Cephalopina titillator. Rev. Elev. Med. Vet. Pays Trop., 42: 27-31.

Oryan, A; Moghaddar, N. and Hanifepour, M.R. (1993): Arthropods recovered from the visceral organs of camel with special reference to their incidence and pathogenesis in Fars Province of Iran. Indian J. of Animal Sci., 63:290-293.

Oryan, A.; Valinezhad, A. and Moraveji, M. (2008): Prevalence and pathology of camel nasal myiasis in eastern areas of Iran. Trop. Biomed., 25: 30-36.

Otranto, D. (2001): The immunology of myiasis: parasite survival and host defense strategies. Trends in Parasitol., 17: 176-182.

Savini, G.; Robertson, I.D. and Dunsmore, J.D. (1997): Sensetivities and specificities of two ELISA tests for detecting infection with sarcocystosis in cattle of Western Australia. Prev. Vet. Med., 32: 35-40.

Sazmand A, and Joachim A. 2017. Parasitic diseases of camels in Iran (1931-2017) - a literature review. Parasit., 24: 1-15.

Shakerian, A.; Hossein, S.R. and Abbasi, M. (2011): Prevalence of Cephalopina titillator (Diptera: Oestridae) larvae in one-humped camel (Camelus dromedarius) in Najaf-Abad, Iran. Glob.Vet., 6: 320-323.

Tabouret, G.; Prevot, F.; Bergeaud, J.P.; Dorchies, P. and Jacquiet, P. (2001): Oestrus ovis (Diptera: Oestridae): sheep humoral immune response to purified excreted/secreted salivary gland $28 \mathrm{kDa}$ antigen complex from second and third instar larvae. Vet. Parasitol., 101: 53-66.

Tabouret, G.; Lacroux, C.; Andreoletti, O.; Bergeaud, J.P.; Hailu-Tolosa, Y., Hoste, H.; Prevot, F.; Grisez, C.; Dorchies, P.H. and Jacquiet, P. (2003): Cellular and humeral local immune responses in sheep experimentally infected with Oestrus ovis (Diptera:Oestridae). Vet. Parasitol., 34: 231-241.

Taylor, M.A.; Coop, R.L. and Wall, R.L. (2007): Veterinary parasitology: Blackwell publishing Ltd,oxford, Uk.

Toaleb, N.I. and Abdel-Rahman, E.H. (2021): Accurate Diagnosis of Camel Nasal Myiasis using Specific Second Instar Larval Fraction of Cephalopina titillator Extract. Advan. in Animal and Vet.Sci., 9: 674-681. 
Wall, R. and Shearer, D. (2001) Veterinary ectoparasites: Biology, pathology and control Oxford, Science Ltd.

Yin, J. and Tian, L. (2014): Joint inference about sensitivity and specificity at the optimal cut-off point associated with Youden index. Comput. Stat. Data Anal., 1-13.
Yousef, H.A.; Abdel Meguid, A.; Afify, A. and Hassan, H.M. (2016): Analysis of larval antigens of Cephalopina titillator in the camel mucus for diagnosis of infestation. Biolo., 71: 438443.

Zumpt, F. (1965): Myiasis of man and animals in the old world: Butterworths, London. 


\section{الملخص العبي}

تقييم المستضدات المختلفة المستخلصة من الطور الثالث ليرقات Cephalopina titillator في عينات المصل والمخاط المجمعة من الابل باستخدام الفحص الانزيمى المرتبط المناعى الغير المباشر

* إيمان أحمد على حسانين و منى محمد إبراهيم عبدالرحمن

قسم الطفيليات -كلية الطب البيطرى -جامعة الزقازيق

تعد الإصابة بيرقاتCephalopina titillator ذات أهمية اقتصادية حيث أظهرت الإبل المصابة مختلف العلامات السريرية و والتي تراوحت بين فقدان الثهية وانخفاض وزن الجسم وإنتاج الحليب إلى ضعف التنفس .كما سجلت الدراسة الحالية معدل انتثار اليرقات عن طريق فحص مابعد الوفاة و الفحص الانزيمى المرتبط المناعى الغير المباشر لعينات

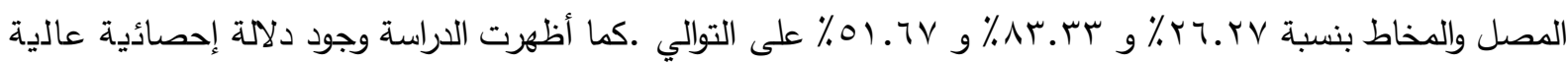
بين مصادر العينة (مصل / مخاط) وأنواع المستضد المستخلصة من يرقات الطور الثالث ( الخام ، محتوى الأعضاء ، منتج إفرازي ،الطبقة الخارجية) اعتمادًا على النتائج التي تم الحصول عليها بواسطة الفحص الانزيمى المرتبط المناعى الغير المباشر. أظهرت الدراسة أن استخدام المستضدات المختلفة يمثل تباينًا معنويًا في النتائج التي تم الحصول عليها باختبار الفحص الانزيمى المرتبط المناعى ، حيث سجل مولد المضاد الخاص بمحتوى الأعضاء أعلى القيم يليه المنتج الإفرازي وأخيراً الطبقة الخارجية كما أظهرت النتائج أن استخدام مولد المضاد لمحتوى الأعضاء للكثف عن الأجسام المضادة في عينات المصل أظهر أعلى قيم معنوية مقارنة مع الأخرى المستخدمة فى اختبارالفحص الانزيمى المرتبط المناعى الغير المباشر. كما أشارت المنطقة الواقعة تحت المنحنى إلى دقة تثخيصية جيدة لاختبار الفحص الانزيمى المرتبط المناعى حيث

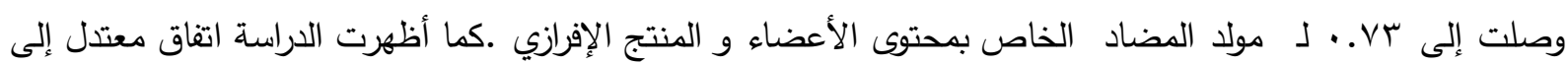
مرتفع بين فحص مابعدالوفاة و الفحص الانزيمى المرتبط المناعى الغير المباشر . استخلصت الدراسة الحالية إلى أن استخدام اختبارالفحص الانزيمى المرتبط المناعى الغير المباشر ضد ضدئ مختلف مستضدات الطور الثالث من C. titillator قد سجل قيم أعلى في مصل الدم عن المخاط حيث تم ترتيب المستضدات بحسب قوتها المناعية على النحو التالي محتوى الأعضاء ثم الخام يليه المنتج الإفرازي وأخيرا الطبقة الخارجية بالنسبه لعينات المصل بينما فى عينات المخاط فقد كانت كالتالى :مولد المضاد لمنتج الإفرازي يليه الخام ثم يتساوى كلا من مولد المضاد لمحتوى الأعضاء و الطبقة الخارجية. وفى نهاية الدراسة نستخلص ان استخدام مولد المضاد الخاص بمحتوى الأعضاء لعينات المصل في الفحص الانزيمى المرتبط المناعى هو الأكثر تعبيرا عن مستوى التعبيرالمناعى حيث أنها تعزز إنتاج الأجسام المناعية(ج) وتوصي الدراسه باستخدام هذا الاختبار للتشخيص المصلي المبكر والدقيق لانتشار C. titillator في لعرئي 
